over these relationships and the response that developed in Ghana. Ghanaians questioned how an empire could claim moral superiority by prohibiting interactions between black males and white females but ignored the fact that white males regularly interacted with black females.

Throughout this engaging work, Ray's use of specific cases serves to draw the reader into what was occurring, and the complexity of the situation. The case of Marcus Clark, for instance, demonstrates the disconnect between the tradition of native wives and its sudden outlawing while also demonstrating, as Clark was West Indian, the complexities of race within the British imperial structure. The same is true of the case of Clarence Curling and the inter-racial marriage rage of 1945. These individual stories demonstrate to us, as Ray's entire work does, the complexity of race and relationships within a colonial setting.

Ty M. Reese

University of North Dakota

\title{
Harvey Amani Whitfield, North to Bondage: Loyalist Slavery in the Maritimes (Vancouver: UBC Press, 2016). 192 pp. \$95.00 Hardcover.
}

In an earlier volume, Blacks Upon the Border: The Black Refugees in British North America, 1815-1900 (2006), Harvey Amani Whitfield offered an admirable study of the black settlers who came to Nova Scotia after the War of 1812. Like their Black Loyalist predecessors after the War of Independence, they often did not receive the lands they were promised for having served the British, or were given inferior allotments that made subsistence difficult. These difficulties notwithstanding, many carved out free lives and created sustainable forms of community. Slavery and indenture, however, were also a common fate of black subjects in Nova Scotia; slavery predated the Loyalists who arrived with their slaves in 1783, free blacks were often forced to indenture themselves, and re-enslavement was a constant risk.

Whitfield's new volume, North to Bondage: Loyalist Slavery in the Maritimes, tells part of that other story. Drawing on data relating to the colonies of Prince Edward Island, Nova Scotia, Cape Breton (Île Royal under the French), and New Brunswick - the latter two were part of Nova Scotia until 1784 Whitfield has produced a thoroughly researched regional study of slavery in the Maritimes. His account is comparative within the Maritime colonies but also with regard to slavery in New England and other parts of the United States, and takes into account the close connections that related the Maritimes through trade, slavery, and migration to the West Indies and the wider British Atlantic.

Citing the more developed scholarship in the United States and the British Caribbean, Whitfield convincingly lays out the case for more detailed work on slavery in the Maritimes. The first monograph on the subject, his book impressively contributes to this task. It draws on a wealth of specific cases drawn from an ap- 
propriately large array of sources, including the 1783 "Book of Negroes," the Loyalist Claims Commission, the Minute Book of Port Roseway Associates, and "slave advertisments, government documents, bills of sale, colonial musters, court, probate, and church records, township books, and oral traditions" (5-6).

To contextualize his subject, Whitfield first adumbrates the situation in the United States where after the revolutionary war an estimated 15,000 slaves and perhaps 8 to 10,000 free African-Americans were dispersed throughout the British Empire. His discussion cites numerous specific cases to account for the relationship between previous experiences in Southern or Northern United States slavery and the new conditions found in the Maritimes. We are then introduced to the earlier Maritimes context, where both the French and English had practiced slavery for over a hundred years. The 1783 arrival of the Loyalists, however, turned it from a marginal institution to wider presence. (Whitfield mentions that in Cape Breton ninety per cent of the slaves were black but does not detail corresponding information for the other colonies; Trudel has shown that approximately two thirds of slaves in New France were Indigenous.)

The main focus of the study is on the transition of slaves from the United States to the Maritimes context, on the work they performed there, the relational situations of slaves and slave holders, and the end and consequences of slavery. Referring to the Maritimes as "a society with slaves" rather than a slave society (49), he shows the wide variety of tasks slaves carried out in this non-plantation economy. A small number of slaves typically worked alongside their owners in what was mainly a subsistence economy. They were "multi-occupational labourers" who carried out every imaginable household and farm work, were active in the fisheries, helped in the clearing and improvement of land and with the building of infrastructure, and engaged in skilled work including carpentry, tailoring, and blacksmithing (53). Whitfield suggests "family slavery" as the best term to characterize this form of slavery typical in the Maritimes. Slaves lived in close proximity to their masters, attended their churches, and were baptized (72). While acts of kindness occurred, Whitfield makes it clear that owners did not refrain from forms of brutality that included sexual assault, flogging, and even murder, in addition to the frequent separation of families. Despite accounts of brutality and occasional court cases, owners were not punished.

Slaves were not entirely powerless, however, forcing a certain element of negotiation in some master-slave relationships. Not only could they withhold some of their work, they frequently ran away, were sheltered by sympathetic whites, and boarded ships in Halifax, Shelburne, or Saint John. In addition, they often found support in the courts (where they were allowed to testify, if sometimes to no avail). While slavery was legalized in Prince Edward Island from 1781 to 1825, it was never recognized under statutory law in New Brunswick and Nova Scotia, despite five attempts by anxious slave "owners" that ran into various kinds of opposition. Especially some Nova Scotia judges put an end to many slave owners' claims. Due to 
such court decisions, the success rate of runaways, and the efforts of sympathetic whites, slavery in Nova Scotia "had probably ceased to exist by the 1820s" (86); as in New England, however, slavery in the Maritimes died a "slow death [that] extended over two decades" (106).

One of the less encouraging reasons for slavery's demise in the Maritimes was its conversion to indentured labour. Cheap black labour, keeping its purveyors in a state of quasi-servitude, was easily available after 1783 because the land promised to the Black Loyalists regularly failed to materialize or proved insufficient. With rising resistance to slavery, the use of cheap black labour and indenture was often the easier solution for white settlers. Even when slavery ended, it "did not end discrimination or open up avenues of political and social inclusion for black people. Instead, they were subject to more insidious forms of racism and hardship. Slavery's demise ... did not result in racial or economic equality" (112). Whitfield thus points to some of the enduring legacies of slavery that continue to make its history relevant to our present.

For students and researchers but also the general public interested in the still often "uncomfortable subject" of slavery in Canada (4), Whitfield's study proves a significant gift (and includes a very useful bibliographic essay). It joins other recent investigations of specific local or regional black histories - such as those by Frank Mackey about black Montreal $(2004,2010)$ or by Ruth Whitehead with regard to the "Book of Negroes" (2013) — that have worked patiently and carefully with many sources to help us better understand how Canada was really built and settled. Whitfield's important and very readable study reinserts Maritimes slavery and black labour into the narrative of Canada's many beginnings while also keeping the relevant black Atlantic connections in full view.

Winfried Siemerling

University of Waterloo

\section{Zouhair Ghazzal, The Crime of Writing. Narratives and Shared Meanings in Criminal Cases in Baathist Syria (Beirut: Presses de l'ifpo). 572 pp, Pa- perback.}

In the last decades research on Ottoman documents from shar'ia courts has contributed to our historical understanding of legal conflicts and their resolutions. Great strides has also been made in the development of research on family lawpersonal status codes - in the Middle East and North Africa. But the same cannot be said for research on contemporary criminal law and cases in criminal courts in the region. There is also a lack of comparative criminal law in both historical and contemporary periods. The Crime of Writing. Narratives and Shared Meanings in Criminal Cases in Baathist Syria is therefore very welcome in beginning to fill such a gap. From 1993 to 2007 Ghazzal collected about one hundred criminal cases which had been 